\title{
STRATEGI PERWUJUDAN KOTA BANDUNG SEBAGAI KOTA RAMAH PENYANDANG DISABILITAS: SEBUAH PERSPEKTIF AKSESIBILITAS PELAYANAN PUBLIK
}

\author{
THE STRATEGY OF TRANSFORMING BANDUNG INTO A \\ DISABILITY-FRIENDLY CITY: A PERSPECTIVE OF PUBLIC \\ SERVICE ACCESSIBILITY
}

\author{
Joni Dawud ${ }^{1}$, Siti Widharetno Mursalim², Endah Tri Anomsari ${ }^{3}$,Nur Imam Taufik ${ }^{4}$ \\ ${ }^{1}$ STIA Lembaga Administrasi Negara Bandung \\ email: joni.dawud@stialanbandung.ac.id \\ ${ }^{2}$ STIA Lembaga Administrasi Negara Bandung \\ email: sitiwidharetno.mursalim@gmail.com \\ ${ }^{3}$ STIA Lembaga Administrasi Negara Bandung \\ email: endah.anomsari@stialanbandung \\ ${ }^{4}$ STIA Lembaga Administrasi Negara Bandung \\ email: nurimamtaufik@gmail.com
}

\begin{abstract}
Abstrak
Dasar penelitian ini diawali dari permasalahan terkait pelayanan bagi penyandang disabilitas yang terjadi khususnya di Kota Bandung. Sebagai warga negara, penyandang disabilitas memiliki hak-hak yang sama untuk hidup secara independen. Hak tersebut hanya bisa dipenuhi apabila fasilitas publik yang mendukung aksesibilitas mereka tersedia dengan baik. Menyadari adanya kebutuhan tersebut, pemerintah Kota Bandung kemudian mencanangkan program untuk membuat Bandung sebagai kota ramah disabilitas. Pendekatan dalam penelitian ini menggunakan pendekatan kualitatif dengan melakukan observasi, wawancara mendalam dan studi literatur. Salah satu strategi yang paling signifikan adalah dengan melakukan pembangunan fasilitas publik yang ramah disabilitas. Namun, temuan empiris di lapangan menujukkan bahwa fasilitas publik belum sepenuhnya bisa diakses oleh penyandang disabilitas. Fasilitas yang ditujukan bagi penyandang disabilitas tidak memberikan manfaat optimal karena belum sesuai dengan desain universal yang berlaku secara internasional. Terdapat beberapa tantangan yang harus dihadapi dalam perwujudan Bandung sebagai penyandang disabilitas. Birokrasi dan masyarakat kurang memiliki kesadaran akan disabilitas dan kesamaan hakhak yang dimiliki para penyandangnya. Koordinasi antarpihak yang terlibat dalam pembangunan fasilitas publik pun belum optimal sehingga ada banyak fasilitas yang direncanakan akan ramah disabilitas pada praktiknya tidak demikian. Pergantian kepala daerah dan dinamika politik juga memungkinkan lambatnya pembentukan regulasi di level daerah terkait dengan pelayanan publik yang peka terhadap kebutuhan penyandang disabilitas. Di tengah tantangan tersebut, mewujudkan Bandung sebagai kota ramah disabilitas masih tetap mungkin dilakukan dengan pilihan strategi yang tepat. Penelitian ini menghasilkan strategi-strategi yang dapat digunakan dalam mewujukan bandung sebagai kota ramah penyandang disabilitas.
\end{abstract}

Kata Kunci: Pelayanan, Aksesibilitas, Disabilitas. 


\begin{abstract}
The basis of this research begins with problems related to services for persons with disabilities that occur especially in the city of Bandung. Indonesian citizens with disability have the right to live independently. The right can only be fulfilled if the accessible public facilities are sufficiently available. Understanding the needs, Bandung City government has set a plan to transform the city into a disability-friendly one by taking several actions, most notably is building public facilities which can be used by everyone. However, the empirical data gathered on the field showcases that public facilities are not accessible by people with disability yet, particularly since they have not met the universal design which applies internationally. The approach in this study is qualitative by conducting observations, in-depth interviews and literature studies. As for the results of the study, there are challenges and strategies to transform Bandung into a disability-friendly city. There are several apparent challenges, such as how bureaucracy and society in the city are lack of awareness about the rights of people with disability. The coordination and communication among actors who are involved in public facilities development are not efficient yet, which results in the ineffective implementation of public service provision. The change of regional legislative and executive head also influences the progress of regional law-making regarding public service which is more considerate of people with disability. In the midst of the challenging situation, realising Bandung as a disability-friendly city is a plausible goal to achieve, with the appropriate strategies as its condition. This research aims to discuss strategies that can be used to transform Bandung into a disability friendly city.
\end{abstract}

Keywords: Public Service, Accessibility, Disability.

\section{PENDAHULUAN}

Di negara-negara Barat, isu tentang aksesibilitas telah lama menjadi perhatian (Vale, 2016). Di Indonesia, isu ini pun sudah mulai menjadi perhatian pemerintah, di antaranya dengan dikeluarkannya Undang-Undang Nomor 8 Tahun 2016 tentang Penyandang Disabilitas. Dalam kebijakan tersebut, aksesibilitas didefinisikan sebagai “...kemudahan yang disediakan untuk penyandang disabilitas guna mewujudkan kesamaan kesempatan". Selanjutnya pada Pasal 18 dalam kebijakan yang sama, dijelaskan bahwa penyandang disabilitas memiliki hak aksesibilitas terhadap dua hal utama, yaitu: pelayanan publik dan akomodasi yang layak.
Fasilitas dan pelayanan publik merupakan satu dari empat aspek yang harus ada dalam perwujudkan aksesibilitas bagi penyandang disabilitas. Fasilitas sendiri tergolong sebagai backbone dalam mewujudkan pelayanan publik yang baik. Yang dimaksud sebagai pelayanan publik di sini meliputi “...penyelenggaran pemberian jasa-jasa publik, urusan-urusan publik (kepentingan dan kebutuhan publik) serta pemberian pelayanan publik yang adil dan tidak diskriminatif" (Kurniawan, 2008). Konsep pelayanan publik yang dikenal sebagai New Public Service (NPS) tersebut menempatkan penerima pelayanan sebagai warga negara, suatu ide yang mengakar 
pada konsep negara kesejahteraan (welfare state) (Puspitosari, 2016).

Pelayanan publik perlu untuk diberikan secara adil dan tidak diskriminatif (Kurniawan, 2008), termasuk kepada penyandang disabilitas. Merupakan warga negara dengan hak-hak yang dilindungi konstitusi, penyandang disabilitas berhak untuk mendapatkan pelayanan prima dalam berbagai bidang kehidupan. Sudah menjadi tanggung jawab pemerintah untuk menyediakan pelayanan yang dapat dinikmati oleh setiap orang. Faktanya, hampir setiap individu akan mengalami disabilitas dalam kehidupannya yaitu pada saat seorang individu sudah pada tahap lanjut usia (Syafi'ie', 2014). Untuk itu, terkait dengan disabilitas, fasilitas publik harus bisa digunakan oleh penyandang disabilitas

Dalam melihat aksesibilitas, kajian dapat dibagi ke dalam dua fokus utama, yaitu: tempat dan kemampuan penyandang disabilitas. Analisis tentang tempat terkait dengan apakah fasilitas dan pelayanan publik sudah mengakomodasi kepentingan dan kebutuhan penyandang disabilitas, sementara analisis kemampuan penyandang disabilitas terkait apakah individual dengan disabilitas sudah dapat menggunakan fasilitas dan pelayanan yang tersedia. Untuk itu dalam konsep aksesibilitas berbicara suatu ukuran kenyamanan atau kemudahan pencapaian lokasi dan hubungannya satu sama lain, mudah atau sulitnya lokasi tersebut dicapai melalui transportasi (Leksono \& dkk, 2010).

Untuk melihat tinggi atau rendahnya aksesibilitas dapat dilihat dari banyaknya sistem jaringan yang tersedia pada daerah tersebut. Semakin banyak sistem jaringan yang tersedia pada daerah tersebut maka semakin mudah aksesibilitas yang didapat begitu pula sebaliknya semakin rendah tingkat aksesibilitas yang didapat maka semakin sulit daerah itu dijangkau dari daerah lainnya (Bhat, 2000).

Adapun untuk melihat kriteria pengukuran aksesibilitas yang ideal dapat dilihat dari 4 (empat) aspek yaitu keamanan, kemudahan, kenyamanan dan estetika (Bhat, 2000). Untuk itu dalam penelitian ini juga akan dijelaskan bagaimana kriteria tersebut dapat memenuhi penyandang disabilitas.

Data statistik menunjukan jumlah penduduk penyandang disabilitas di Indonesia mengalami peningkatan setiap tahunnya. Menurut data PUSDATIN dari Kementerian Sosial (ILO, 2018), pada tahun 2010, jumlah penyandang disabilitas di Indonesia mencapai 11,580,117 orang, di antaranya $\quad 3,474,035 \quad$ (disabilitas penglihatan), 3,010,830 (disabilitas fisik), 2,547,626 (disabilitas pendengaran), 1,389,614 disabilitas mental) and 1,158,012 (disabilitas kronis). Sementara menurut data Kementerian Tenaga Kerja dan 
Transmigrasi, pada 2010 jumlah penyandang disabilitas adalah: 7,126,409 orang. Angka ini memang terlihat kecil dibandingkan dengan total jumlah penduduk Indonesia yang berkisar di angka 261,9 juta jiwa (Badan Pusat Statistik, 2017). Walaupun demikian pelayanan publik harus berlaku adil bagi setiap warga negara.

Beberapa tahun kebelakang ini, Kota Bandung sedang gencar-gencarnya membangun fasilitas fisik terkait pengembangan tata kotanya di mulai dari pembangunan trotoar, jalan khusus sepeda, taman, alun-alun dan fasilitas publik lainnya. Kenyataan di lapangan menunjukan bahwa aksesibilitas Kota Bandung banyak yang belum memenuhi standar universal design dan kriteria pengukuran aksesibilitas yang dtentukan sehingga banyak yang belum berfungsi secara optimal bagi penyandang disabilitas. Dalam penelitian ini penulis memfokuskan pada aksesibilitas pelayanan publik Kota Bandung.

Kajian tentang pelayanan terhadap penyandang disabilitas sudah dilakukan oleh peneliti sebelumnya, diantaranya strategi pemerintah Kota Banda Aceh dan Kota Surakarta dalam mewujudkan kota ramah disabilitas (Suhendra, 2017). Dari penelitian ini dapat diketahui bahwa strategi yang dilakukan oleh Kota Banda Aceh untuk mewujudkan Kota Ramah Disabilitas (KRD) adalah dengan memberikan duungan di bidang pendidikan dengan mendirikan sekolah-sekolah bagi kaum difabel. Selain itu dikeluarkannya kebijakan agar kaum difabel dapat mengakses fasilitas perumahan yang terjangkau. Tujuannya agar penyandang disabilitas dapat melebur di kehidupan masyarakat. Sedangkan Kota Surakarta lebih banyak melakukan dukungan sosial dengan memberikan bantuan sosial bagi penyandang disabilitas yang masuk dalam kriteria miskin. Dari strategi yang dilakukan oleh pemerintah daerah Aceh maupun Surakarta terlihat perbedaan bahwa dalam penelitian yang penulis lakukan di Kota Bandung fokus dalam penelitian penulis lebih menekankan pada aksesibilitas fisik yang memadai bagi kaum disablitias. Mengingat Kota Bandung sedang gencar-gencarnya melakukan pembangunan kotanya.

Selain itu, bila melihat penelitian tentang pelayanan publik bagi pemenuhan hak-hak disabilitas di Kota Yogyakarta (Rahayu \& Dewi), strategi yang dilakukan Kota Yogyakarta menekankan kepada pendidikan yang layak bagi kaum disabilitas dengan adanya kurikulum SLB yang sesuai dengan standar, ditambah lgi dengan dibuatnya Blind Corner di Perpustakan Daerah juga program-program rehabilitasi dan pelayanan sosial. Selain 
dukungan pendidikan juga dukungan dibidang transportasi seperti Transjogja, Terminal Giwangan yang dapat diakses oleh Kaum Disabilitas. Berbicara penelitian ini menjadi menjadi acuan dalam penelitian di Kota Bandung yang mana Kota Bandung melakukannya dengan lebih komprehensif dalam aspek aksesibilitas fisik dengan mendukung Kotanya tidak hanya melalui transportasi namun gedung-gedung publik dan ruang-ruang publik menjadi prioritas.

Untuk itu tujuan dalam penelitian ini akan dibahas bagaimana strategi lebih lanjut untuk menjadikan Kota Bandung sebagai kota ramah penyandang disabilitas dalam perspektif aksesibilitas pelayanan publik.

\section{METODE PENELITIAN}

Desain penelitian ini menggunakan pendekatan kualitatif. Pendekatan kualitatif digunakan untuk mengungkapkan secara komprehensif, mendalam dan apa adanya bagaimana perwujudan Kota Bandung sebagai kota ramah penyandang disabilitas yang dilihat dari perspektif aksesibilitas pelayanan publik. Adapun teknik pengumpulan data dengan menggunakan studi literatur dan lapangan baik observasi dan wawancara mendalam. Adapun penentuan informan dilakukan denga purposive sampling yaitu informan yang dianggap memiliki pengetahuan atau informasi terkait perwujudan Kota Bandung sebagai Kota Ramah Disabilitas yang terdiri dari Dinas Sosial, Dinas Perhubungan, Dinas Pekerjaan Umum, Komunitas Penyandang Disabilitas dan Organisasi pemerhati penyandang disabilitas dalam hal ini adalah Bandung Independet Living Centre (BILIC). Analisis data diawal dengan reduksi, penyajian data dan penarikan kesimpulan (verifikasi). Penelitian ini dilakukan dari bulan Maret sampai dengan November 2018.

\section{HASIL PENELITIAN}

Penelitian ini mendeskripsikan dua bagian yaitu, dasar kebijakan penyandang disabilitas serta bagaimana aksesibilitas bagi penyandang disabilitas di Kota Bandung. Hal pertama terkait dengan dasar kebijakan penyandang disabilitas diawali dari diratifikasinya konvensi untuk hak-hak penyandang disabilitas (CRFD) yang disahkan oleh PBB yang melahirkan UU No. 19 Tahun 2011 yang menempatkan disabilitas sebagai suatu prioritas isu dalam pemerintahan sehingga dapat terimplementasikan dalam seluruh penyelenggaraan pemerintahan baik ditingkat pusat hingga tingkat daerah hingga pada akhirnya dikeluarkannya UU No. 8 Tahun 2016 tentang penyandang disabilitas untuk menghilangkan pembatasan dan hambatan bagi penyandang 
disabilitas sehingga dapat mengurangi hak penyandang disabilitas sebagai warga negara Indonesia. Undang-undang ini juga sebagai bentuk dari penjabaran UU No. 25 Tahun 2009 tentang pelayanan publik. Dalam UU ini ditegaskan bahwa pelayanan publik harus memenuhi asas-asas pelayanan publik, diantaranya asas kepentingan umum, kepastian hukum, kesamaan hak, keseimbangan hak dan kewajiban, profesional, partisipatif, persamaan perlakuan/tidak diskriminatif, keterbukaan, akuntabilitas, fasilitas dan perlakuan khusus bagi kelompok rentan, ketepatan serta kecepatan, kemudahan dan keterjangkauan untuk memberikan pelayanan yang cepat, mudah dan terjangkau.

Pasal 29 UU No. 25 Tahun 2009 disebutkan pula bahwa penyedia layanan harus memberikan layanan khusus bagi penyandang disabilitas serta pemanfaatan sarana, prasarana dan/atau fasilitas pelayanan publik yang sesuai bagi para penyandang disabilitas tanpa boleh dipergunakan oleh orang yang tidak berhak. Dari pasal ini menjadi acuan bagi seluruh penyelenggara pemerintah pusat dan daerah untuk memberikan kesamaan dan kemudahan layanan kepada penyandang disabilitas.

Political will pemerintah tertuang kembali dalam Peraturan Menteri Pekerjaan
Umum No. 30 Tahun 2006 terkait pedoman teknis fasilitas dan aksesibilitas pada bangunan gedung dan lingkungan yang mengharuskan seluruh fasilitas harus mudah dan aman bagi penyandang disabilitas. Selain itu terdapat Keputusan Menteri Perhubungan No. KM 71 Tahun 1999 tentang Aksesibilitas Bagi Penyandang Cacat dan Orang Sakit pada Sarana dan Prasarana Perhubungan”.

Dari seluruh aturan yang ada terkait penyandang disabilitas yang dikeluarkan oleh pemerintah pusat, Bandung sebagai salah satu kota besar di Indonesia belum memiliki aturan terbaru mengenai penyandang disabilitas. Aturan baru sebatas perda No. 26 Tahun 2009 tentang Kesetaraan Pemberdayaan Penyandang Cacat. Dalam aturan ini tentunya masih berdasarkan aturan lama belum mengacu kepada UU No 8 Tahun 2018. Penyebutan nomenklatur pun masih menggunakan kata cacat yang sangat terkait dengan isu ketidaksetaraan. Ridwan Kamil selaku walikota Bandung periode 2013 s.d. 2018 pernah mencanangkan Bandung sebagai Kota Inklusi. Komitmen tersebut rencananya akan didukung oleh lahirnya peraturan walikota (perwal) tentang disabilitas. Namun, hingga saat ini perwal tersebut belum ada.

Hal kedua terkait bagaimana disabilitas di Kota Bandung dapat dilihat 
dari jumlah penyandang disabilitas yang terus mengalami peningkatan yang semula pada tahun 2015 sebanyak 4123 hingga akhir tahun 2017 mencapai 5359 (Dinas Sosial Kota Bandung, 2018)

Selain dilihat dari jumlahnya, penyandang disabilitas di Kota Bandung juga mengalami berbagai permasalahan. Masalah-masalah tersebut memang cukup prevalen di Indonesia sehingga juga dialami oleh penyandang disabilitas di Kota Bandung, di antaranya adalah penilaian atau stigma masyarakat yang mana penyandang disabilitas seringkali dipandang sebagai seorang yang "cacat" sehingga mereka tidak dapat berpartisipasi secara penuh di dalam masyarakat. Mobilitas dan aksesibilitas pelayanan publik pun perlu untuk dibenahi, mengingat penyandang disabilitas di Kota Bandung seringkali mengalami kesulitan untuk berpindah dari satu tempat ke tempat lain di dalam kota karena fasilitas publik yang tidak ramah terhadap disabilitas. (BILIC, 2018)

Bandung saat ini sudah menunjukan adanya perubahan terkait pelayanan publik yang diberikan kepada masyarakat. Dalam pembangunannya, pemerintah Kota Bandung mengawali dengan melakukan pembenahan di berbagai fasilitas publik di berbagai sudut kota. Hasilnya, Bandung saat ini terlihat berbeda dari sebelumnya.
Banyak taman-taman publik yang dibuat sebagai ruang publik bagi masyarakat yang ingin menikmati Bandung, perbaikan trotoar di sejumlah ruas, perbaikan gedunggedung pemerintahan dan pelestarian gedung-gedung bersejarah.

Pelayanan publik diberikan sebagai bentuk pelaksanaan kewajiban pemerintah untuk memenuhi hak masyarakat tanpa kecuali termasuk penyandang disabilitas. Beberapa fasilitas publik sudah dapat di akses oleh penyandang disabilitas seperti di daerah Cihampelas dan alun-alun Kota Bandung. Namun, bagaimana dengan kebermanfatannya perlu dilihat dari perspektif penyandang disabilitas itu sendiri. Adapun penyandang disabilitas yang paling bersentuhan dengan aksesibilitas fisik pelayanan publik ialah penyandang disabilitas daksa, netra dan rungu/wicara serta grahita.

Komitmen pemerintah Bandung terlihat dari beberapa organisasi yang dibentuk pemerintah yang menaungi disabilitas di antaranya DPW PPDI, HWDI (dan organisasi disabilitas sesuai dengan jenis disabilitasnya seperti Gerakan Tunarungu, dan Persatuan Tunanetra. Melalui organisasi-organisasi tersebut munculah komunikasi dua arah antara pemerintah Kota Bandung dan penyandang disabilitas dengan forum-forum diskusi yang sering diagendakan oleh pemerintah 
Kota Bandung baik oleh Dinas Sosial, Dinas Pekerjaan Umum, Dinas Perhubungan dan Dinas Ketenagakerjaan.

Forum-forum yang dibuat untuk menjaring aspirasi serta kebutuhan para penyandang disabilitas. Begitupun dengan rencana pembangunan Kota Bandung, pemerintah menggelar FGD dengan penyandang disabilitas di setiap perencanaan proyek pembangunan. Hal ini dilakukan agar pembangunan yang dihasilkan dapat dinikmati oleh seluruh masyarakat Kota Bandung.

Dari hasil wawancara dengan penyandang disabilitas menyatakan:

"Pemkot sering ngundang untuk rapat, diskusi termasuk juga untuk negbangun halte metro, disini kami menyampaikan kalau penyandang disabilitas butuh hidrolik untuk bisa naik ke halte soalnya kan tangganya tinggi dan curam dan disitu pemerintah setuju untu ngebangun hidrolik tapi pelaksanannya ngga, dan kami ga pernah diajak pada saat proses pembanguannya. Inginnya kami dilibatkan untuk pengawasannya”. (Disabilitas, 2018)

Dari wawancara tersebut diketahui bahwa pemerintah memang sering mengadakan FGD terkait isu-isu atau pembangunan yang berkaitan dengan penyandang disabilitas. Namun, penyandang disabilitas biasanya hanya dilibatkan pada saat perencanaan. Sedangkan pada tahap pelaksanaan pembangunan, mereka tidak dilibatkan dalam pengawasannya sehingga tidak jarang hasil yang diperoleh tidak sesuai dengan kebutuhan penyandang disabilitas.

Selain itu, diketahui pula bahwa kaum difabel sangat kesulitan dalam mengakses berbagai tempat umum, gedung perkantoran, serta angkutan. Kesulitan aksesibilitas ini terkait hambatan arsitektural di Kota Bandung. Untuk itu penulis menyajikan berbagai hambatan yang penulis dapatkan selama melakukan wawancara dan observasi di Kota Bandung.

Tabel 1

Hambatan Arsititektural Bagi

Penyandang Disabilitas di Kota Bandung

\begin{tabular}{|c|c|c|}
\hline No. & $\begin{array}{l}\text { Kategori } \\
\text { Disabilitas }\end{array}$ & Hambatan \\
\hline \multirow{9}{*}{1} & \multirow{9}{*}{$\begin{array}{l}\text { Disabilitas } \\
\text { Fisik }\end{array}$} & $\begin{array}{l}\text { Permukaan jalan kota yang tidak } \\
\text { rata sehingga menghambat } \\
\text { jalannya kursi roda. }\end{array}$ \\
\hline & & $\begin{array}{l}\text { Ram / jalan landai tidak banyak } \\
\text { tersedia di berbagai fasilitas kota } \\
\text { (gedung, batas trotoar dan jalan). }\end{array}$ \\
\hline & & $\begin{array}{l}\text { Ukuran kemiringan ram / tangga } \\
\text { landai yang tidak sesuai dengan } \\
\text { standar. }\end{array}$ \\
\hline & & $\begin{array}{l}\text { Toilet khusus disabilitas belum } \\
\text { tersedia diseluruh fasilitas publik. }\end{array}$ \\
\hline & & $\begin{array}{l}\text { Ukuran toilet khusus disabilitas } \\
\text { yang tersedia ada yang ukurannya } \\
\text { tidak sesuai dengan standar. }\end{array}$ \\
\hline & & $\begin{array}{l}\text { Tidak adanya tangga khusus untuk } \\
\text { menggunakan transportasi publik. }\end{array}$ \\
\hline & & $\begin{array}{l}\text { Belum ada tangga khusus di setiap } \\
\text { halte Kota Bandung. }\end{array}$ \\
\hline & & $\begin{array}{l}\text { Tombol-tombol yang letaknya } \\
\text { terlalu tinggi. }\end{array}$ \\
\hline & & $\begin{array}{l}\text { Pintu putar / otomatis bergerak } \\
\text { terlalu cepat. }\end{array}$ \\
\hline \multirow{3}{*}{2} & \multirow{3}{*}{$\begin{array}{l}\text { Disabilitas } \\
\text { Sensorik }\end{array}$} & $\begin{array}{l}\text { Guiding block bagi tunanetra } \\
\text { belum terpasang dengan baik } \\
\text { bahkan disejumlah jalan banyak } \\
\text { yang terputus/rusak. }\end{array}$ \\
\hline & & $\begin{array}{l}\text { Tidak ada petunjuk terhadap nomor } \\
\text { lantai pada gedung ataupun arah } \\
\text { jalan. }\end{array}$ \\
\hline & & $\begin{array}{l}\text { Terdapat lift yang tombolnya tidak } \\
\text { dapat diraba (petunjuk taktual). }\end{array}$ \\
\hline
\end{tabular}




\begin{tabular}{cl}
\hline & $\begin{array}{l}\text { Adanya papan reklame yang } \\
\text { dipasang ditempat pejalan kaki. }\end{array}$ \\
\cline { 2 - 2 } & $\begin{array}{l}\text { Tunarungu tidak dapat mendengar } \\
\text { pengumuman melalui pengeras }\end{array}$ \\
& $\begin{array}{l}\text { suara seperti di bandara, terminal } \\
\text { dan fasilitas publik lainnya, }\end{array}$ \\
\cline { 2 - 2 } & $\begin{array}{l}\text { Tunarungu tidak dapat mendengar } \\
\text { ketika terjadi bunyi tanda bahaya. }\end{array}$ \\
\hline \multirow{2}{*}{ Disabilitas } & $\begin{array}{l}\text { Kesulitan dalam mencari jalan } \\
\text { selama tidak terdapat petunjuk } \\
\end{array}$ \\
& yang jelas. \\
\hline
\end{tabular}

Sumber: Hasil Wawancara dan Observasi, 2018.

Berbagai upaya sudah banyak dilakukan oleh organisasi penyandang disabilitas untuk memperjuangkan haknya.

\section{BILIC (Bandung Independence Living}

Centre) sebagai satu-satunya organisasi penyandang disabilitas non bentukan pemerintah sudah melakukan berbagi macam upaya dari mulai menyampaikan naskah akademik kepada pemerintah Kota Bandung, petisi, bahkan demo. Namun, pihak BILIC menyatakan respon pemerintah terhadap pemenuhan penyandang disabilitas ini tidak berjalan terus menerus sehingga akhirnya dalam rangka mewujudkan hak-hak penyandang disabilitas, BILIC banyak dibantu oleh NGO dari luar Indonesia (BILIC, 2018)

Mengulas dari tanggapan pemerintah dan masyarakat dapat terlihat bahwa responsivitas pemerintah Kota Bandung masih rendah terhadap penyandang disabilitas. Hal ini disebabkan adanya persepsi pemerintah yang tidak tepat terhadap keberadaan masyarakat yang memiliki kebutuhan khusus. keberadaan penyandang disabilitas yang jumlahnya sangat sedikit dibandingkan dengan jumlah masyarakat umumnya di Kota Bandung, sehingga tidak banyak kebijakan yang dibuat terkait penyandang disabilitas, tidak adanya reward dan punishment yang jelas bagi pihak-pihak yang telah membantu terwujudnya aksesibilitas bagi penyandang disabilitas ataupun pihak yang tidak turun serta dalam perwujudan aksesibilitas. Selain itu, dalam perencanaan penganggaran, penyediaan aksesibilitas bagi penyandang disabilitas bukan menjadi prioritas, kurangnya sosialisasi kebijakan terkait penyediaan aksesibilitas bagi penyandang disabilitas, mindset aparatur pemerintah yang secara umum belum berpihak pada penyandang disabilitas, pemerintah menempatkan penyandang disabilitas sebagai "objek" bukan sebagai "subjek" yang dapat berdaya guna dan berhasil guna. Terakhir, nanyaknya program pemberdayaan yang tidak tuntas. (Firdaus \& Iswahyudi, 2010)

Berkaitan dengan respon masyarakat secara umum, peran masyarakat dalam menciptakan kota ramah penyandang disabilitas perlu didukung oleh lingkungan masyarakat yang ramah terhadap disabilitas. Dalam konteks ini masyarakat perlu teredukasi bahwa penyandang disabilitas merupakan warga negara yang memiliki hak dan kewajiban yang sama, 
bukan menjadi bagian yang berbeda. Masyarakat pada umumnya lebih merasa terharu dan kasihan melihat penyandang disabilitas sehingga menganggap penyandang disabilitas adalah orang yang berbeda dan perlu dibantu, padahal penyandang disabilitas perlu dikuatkan kemandiriannya bukan terus menerus dibantu. (BILIC, 2018) Tentunya hal ini perlu dukungan fasilitas dari pemerintah.

Dwiyanto (2012) membagi sikap masyarakat ke dalam beberapa kelompok, diantaranya kelompok apatis yang tidak memperdulikan keberadaan penyandang disabilitas, kelompok pasif sebagai kelompok yang mengenal disabilitas dan pernah berinteraksi, namun tidak tahu harus berbuat apa, kelompok penyantun yang memandang penyandang disabilitas sebagai objek santunan karena perasaan belas kasihan dan kelompok pemberdaya yang melihat disabilitas sebagai persoalan ketidakadilan. Kelompok ini berpendapat bahwa santunan bukan cara yang tepat untuk menyelesaikan permasalahan disabilitas. Cara yang tepat adalah dengan mengembalikan hak-hak penyandang disabilitas untuk menciptakan ruang yang aksesibel agar mereka dapat hidup sebagaimana masyarakat pada umumnya.

Dari perbedaan-perbedaan tersebut maka edukasi dini terhadap penyandang disabilitas perlu dilakukan secara komprehensif dengan melibatkan pemerintah, swasta dan masyarakat sehingga apa yang harus diperbuat kepada penyandang disabilitas selayaknya merupakan hal yang berujung kepada kemandirian dan berdaya guna.

\section{PEMBAHASAN}

Dari hasil penelitian selanjutnya akan dibahas terkait aksesibilitas yang akan dijabarkan dalam empat kriteria yaitu: keamanan, kemudahan, kenyamanan dan estetika (Bhat, 2000) serta strategi dalam mewujudkan kota ramah disabilitas.

Kriteria pertama yaitu keamanan. Hal ini dapat dilihat dari sejauhmana Kota Bandung dapat menjamin penyandang disabilitas dalam hal keamanannya. Diantaranya keamanan dalam segi kejahatan ketika sedang menggunakan fasilitas umum baik gedung, jalan dan transportasi. Dalam hal ini pemerintah Kota Bandung belum dapat menjamin hal ini, sesuai dengan apa yang dinyatakan dalam hasil wawancara:

"Kalau kami berpergian atau pergi ke gedung-gedung seringkali dijalan ada orang-orang yang berusaha berbuat ngga baik, bahkan di bis atau angkot ada yang nyopet juga" (Disabilitas, 2018).

Keamanan dapat dilihat juga dari kondisi trotoar, lebar trotoar dan jalur khusus untuk penyandang disabilitas. Bila menilik kondisi trotoar yang ada di Kota Bandung, kondisi di jalan protokol seperti 
di daerah dago, martadinata, merdeka, alunalun bandung terlihat trotoarnya sudah rapih dan besar, namun pemerintah menempatkan hiasan batu-batu bulat ditengah trotar yang menurut ketua penyandang disabilitas Kota Bandung sangat mengganggu bagi penyandang disabilitas yang melewati trotoar tersebut. Belum lagi beberapa trotoar tidak memiliki guiden block. Bila pun ada seperti di daerah Cihampelas kondisi guiden block banyak yang rusak dan bolong-bolong. Hal ini tentunya sangat merugikan penyandang disabilitas dalam mengakses Kota Bandung yang seharusnya menjadi hak setiap warga negara untuk mendapatkan fasilitas yang layak.

Kriteria kedua yaitu kemudahan. Kemudahan yang disampaikan Baht terkait bagaimana hubungan dari satu tempat ke tempat lain serta sarana dan prasarana yang mendukung hal tersebut. Dalam hal ini kemudahan trasnportasi menjadi salah satu pertimbangan aksesibilitas dapat dinyatakan baik atau tidak.

Melihat kondisi transportasi umum di Kota Bandung, masih banyak hal yang perlu ditingkatkan. Dalam hal ini pemerintah sudah menyediakan layanan transportasi umum seperti Damri dan Trans Metro Bandung. Di dalamnya pun sudah menyediakan ruang khusus untuk penyandang disabilitas. Walaupun seringkali tempat ini masih digunakan oleh masyarakat non disabilitas. Hal yang menyulitkan lainnya adalah terkait ketidaktersediannya hidrolik di halte Trans Metro Bandung sehingga menyulitkan penyandang disabilitas untuk menuju halte. Padahal dalam rencana pembuatannya akan disediakan hidrolik namun dalam implementasinya sampai hari ini belum tersedia (Disabilitas, 2018).

Kriteria ketiga yaitu kenyamanan yang berkaitan dengan bagaimana fasilitas dirancang untuk memberikan kenyamanan bagi penyandang disabilitas seperti area teduh dihalte, tempat duduk di halte, tingkat kemiringan trotoar, dll.

Menyikapi hal ini, sebagian besar jalan protokol di Kota Bandung sudah menyediakan trotoar yang lebar serta tempat duduk yang tersedia di sepanjang jalan sehingga dapat dinikmati oleh masyarakat ketika melewati berjalan di trotoar tersebut. Halte pun sudah tertutup hanya saja masih banyak halte yang kebersihannya kurang bahkan banyak ditinggali oleh para tunawisma sehingga menjadi tidak nyaman. Terkait kemiringan trotoar memang masih ada trotoar yang tidak memberikan sudut elevasi untuk dapat dilalui oleh kursi roda. Hal ini pun menyulitkan bagi disabilitas yang menggunakan kursi roda.

Kriteria keempat yaitu estetika. Estetika terkait bagaimana desain fasilitas 
yang dibuat memiliki nilai estetika yang dapat memberikan nilai lebih bagi penggunanya. Estetika disini dapat dilihat dari pemandangan lanskap yang tersedia.

Dalam hal ini, beberapa fasilitas publik menyediakan pemandangan yang indah diantaranya taman-taman kota yang memiliki estetika yang baik. Hanya saja estetika ini juga harus didukung fasilitas lainnya sehingga selain indah juga nyaman.

Dari empat kriteria yang telah dibahas, untuk itu diperlukan strategi dalam mewujudkan kota ramah penyandang disabilitas yang diawali dengan perbandingan beberapa konsep terkait kota ramah disabilitas. Diantaranya terdapat konsep desain universal (universal design). Konsep desain universal UN Convention on Rights of Persons with Disabilities (CRPD) merupakan pedoman bagi berbagai negara untuk menciptakan negara/ kota yang layak, efektif, fleksibel dan inklusi. Namun desain ini tidak menjadi sebuah kewajiban, desain ini dapat dimodifikasi sesuai dengan karakter dan kebutuhan suatu negara/ kota. (Snider \& Takeda, 2008)

Untuk itu Kota Bandung dapat mengadopsi desain universal sebagai pedoman pembangunan tata kota. Beberapa konsep aksesibilitas fisik yang ditawarkan dalam universal design diantaranya sistem transportasi yang mudah diakses sebagaimana tabel 2 .
Tabel 2

Prioritas Sistem Transportasi yang Mudah di Akses

\begin{tabular}{|c|l|l|l|}
\hline \multicolumn{2}{|c|}{ Marginal } & \multicolumn{1}{|c|}{ Typical Intervention } & \multicolumn{1}{c|}{ Probable Priority } \\
\hline Cost & Benefit & \multicolumn{1}{|c|}{$\begin{array}{l}\text { Visual contrast, color coding, } \\
\text { clear/intuitive signs, longer } \\
\text { green signals }\end{array}$} & $\begin{array}{l}\text { Essential-these should be } \\
\text { established design practice }\end{array}$ \\
\hline Bone & Broad & $\begin{array}{l}\text { Basic sidewalk and crosing } \\
\text { design, hazard markings, } \\
\text { minimize steps and other } \\
\text { hazards }\end{array}$ & $\begin{array}{l}\text { Very high-should be } \\
\text { established design practice }\end{array}$ \\
\hline High & Broad & $\begin{array}{l}\text { Raised pedestrian crossings, } \\
\text { raised boarding platforms or } \\
\text { low-floor vehicles, general } \\
\text { training of operational staff }\end{array}$ & $\begin{array}{l}\text { High-should be considered } \\
\text { practice for safe street } \\
\text { environment. Subject to } \\
\text { resources }\end{array}$ \\
\hline Low & Specific & $\begin{array}{l}\text { User awareness, prioritu } \\
\text { seating, additional training of } \\
\text { operational staff, tactile } \\
\text { surfaces, curb cuts insets }\end{array}$ & $\begin{array}{l}\text { Very high-subject to policy for } \\
\text { resource allocation }\end{array}$ \\
\hline High & Specific & $\begin{array}{l}\text { Elevators, illuminated and } \\
\text { audible signals, whwwlchair } \\
\text { location, special transport } \\
\text { services. }\end{array}$ & $\begin{array}{l}\text { High-subject to policy for } \\
\text { resource allocation }\end{array}$ \\
\hline
\end{tabular}

Sumber: (Snider \& Takeda, 2008)

Dari tabel tersebut dapat diketahui

bahwa hal yang paling dasar untuk mewujudkan sistem transportasi kota yang inklusi, maka transportasi harus memiliki warna yang kontras serta tanda yang jelas. Curb menjadi prioritas yang cukup tinggi dalam pertimbangan sistem transportasi yang mana desain antar jalan dan trotoar harus memiliki curb yang bisa diakses oleh penyandang disabilitas. Tinggi halte dengan tinggi pintu masuk bis pun harus sama sehingga memudahkan bagi penyandang disabilitas yang menggunakan kursi roda. Prioritas yang cukup tinggi lainnya adalah ketersediannya ruang di dalam lift untuk kursi roda serta tombol-tombol yang bisa diraba beserta suara pengeras yang menandakan lift berada di lantai berapa serta suara yang menandakan pintu sedang terbuka atau tertutup. Sedangkan prioritas 
yang masuk ke dalam skala sangat tinggi adalah desain trotoar beserta persimpangan dalam jalan raya dan tanda bahaya harus dibuat khusus. Prioritas tertinggi lainnya adalah perlunya kesadaran pengguna terhadap tempat-tempat yang khusus dibuat untuk penyandang disabilitas seperti tempat duduk khusus disabilitas. Selain kesadaraan pengguna/masyarakat secara umum, perlu juga adanya pelatihan khusus bagi staf/pegawai yang berhubungan dengan pelayanan secara langsung terhadap penyandang disabilitas.

Hal tersebut tentunya dapat menjadi acuan dalam upaya membangun kota yang ramah penyandang disabilitas. Dalam hal ini diperlukan banyak masukan dari masyarakat khususnya penyandang disabilitas dari berbagai jenis disabilitas terkait hambatan-hambatan apa yang mereka temui dalam mengakses transportasi di Kota Bandung sehingga akan membantu dalam memprioritaskan fitur transportasi yang mudah di akses.

Untuk mempermudah ini, diperlukan juga komite yang terdiri dari orang-orang yang memiliki pengetahuan yang beragam dari jenis disabilitas yang berbeda untuk meninjau perencanaan dan pelaksanaan sistem transportasi sehingga dapat meminimalisir kesalahan dalam pembuatan dan tentunya dapat betul-betul diakses oleh penyandang disabilitas. Dalam hal ini Kota
Bandung belum sepenuhnya melakukan ini, komunitas penyandang disabilitas baru sebatas diikutsertakan dalam perencanaan, namun tidak dilibatkan dalam pemantauan pembuatan aksesibilitas yang sudah disepakati dalam perencanaan. Alhasil banyak sistem transportasi kota yang tidak bisa digunakan. Untuk itu kerjasama yang baik diperlukan antara pemerintah, komunitas penyandang disabilitas dan penyedia transportasi.

Selain itu perlu adanya perbaikan tata kota. Pertumbuhan sebuah kota pada dasarnya berjalan secara alami. Namun, ketika pemerintah sudah mencanangkan beberapa proyek untuk membangun kotanya maka indikator baik tidaknya pembangunan adalah tergantung kepada keberhasilan sebuah kota dalam memberikan manfaat yang optimal bagi masyarakat tanpa melihat perbedaan dalam hal ini berlaku pula untuk penyandang disabilitas.

Faktanya, sering terlihat di Kota Bandung ini jalan-jalan yang padat dan berbahaya misalkan banyak jalanan yang rusak, trotoar yang berlubang, selokan dan saluran air yang terbuka. Semua ini tentunya mengancam orang-orang yang melintasinya terlebih lagi anak-anak, orang tua dan penyandang disabilitas. Untuk itu perlu dilakukan analisis kondisi fisik yang ada di Kota Bandung seperti reklame, 
lampu lalu lintas, penerangan, tempat sampah, tempat duduk, letak pohon, tiang listrik dsb. Jangan sampai keberadaan furniture fisik tersebut menjadi tidak berguna bahkan menganggu keselamatan penyandang disabilitas. Analisis kondisi fisik ini perlu juga melibatkan penyandang disabilitas sehingga akan ditemukan kondisi fisik yang layak ataupun tidak layak di Kota Bandung.

Dari konsep desain universal yang ditawarkan, secara teknis sebaiknya pembangunan Kota Bandung mencoba mengadopsi sesuai dengan karakteristik yang dibutuhkan oleh Kota Bandung. Namun, bila berbicara strategi mewujudkan Kota Bandung dalam aspek yang lebih komprehensif antara lain sebagai berikut:

Pertama, perlu adanya pembuatan peraturan terkaitan penyandang disabilitas di Kota Bandung yang dapat berwujud peraturan walikota. Aturan ini juga harus berisikan kewajiban pihak swasta untuk turut berperan aktif dalam mewujudkan kebutuhan fasilitas penyandang disabilitas.

Kedua, penguatan koordinasi antar lembaga maupun intra lembaga sehingga peraturan dapat diimplementasikan sesuai dengan yang telah ditetapkan.

Ketiga, pelibatan penyandang disabilitas, komunitas, organisasi, LSM yang memiliki konsentrasi terhadap penyandang disabilitas dari mulai perencanaan pembangunan hingga pengawasan pembangunan.

Keempat, sosialisasi yang jelas kepada seluruh stakeholder baik eksekutif, legislatif dan masyarakat secara luas terkait dengan hak penyandang disabilitas untuk menjalankan kehidupannya secara mandiri sehingga diperlukan aksesibilitas fisik yang mendukung.

Kelima, adanya pendidikan dini terhadap aksesibilitas disabilitas melalui jalur pendidikan untuk menciptakan kesadaran masyarakat.

Keenam, dukungan anggaran dalam pembangunan akesibilitas fasilitas penyandang disabilitas seperti trotoar, zebra cross, jembatan penyebrangan, toilet khusus disabilitas, dll.

Ketujuh, perbaikan gedung-gedung pemerintahan, sekolah, pusat perbelanjaan, halte, terminal, stasiun, perkantoran, tempat wisata dan tempat ibadah termasuk juga perbaikan transportasi agar dapat digunakan oleh penyandang disabilitas.

Kedelapan, Pemerintah memberikan reward kepada pihak-pihak yang telah bekerjasama membantu mewujudkan fasilitas bagi penyandang disabilitas. Serta pengrajin yang dapat memproduksi barangbarang kebutuhan khusus penyandang disabilitas.

Kesembilan, mendorong percepatan regulasi di tingkat lokal dan penguatan 
koordinasi. Mempertimbangkan bahwa salah satu tantangan yang muncul dalam mewujudkan Bandung sebagai kota yang ramah disabilitas, khususnya dilihat dari aspek akesibilitasnya, adalah lambatnya regulasi di tingkat lokal, percepatan penyusunan regulasi perlu untuk dilakukan. Percepatan regulasi ini bertujuan agar ada aturan di tingkat lokal yang mengacu pada UU No. 8 Tahun 2016 untuk dijadikan sebagai acuan teknis bagi organisasi perangkat daerah dalam mewujudkan fasilitas publik yang ramah disabilitas. Selain itu, regulasi di tingkat lokal juga harus mulai mempertimbangkan pembentukan sistem reward and punishment yang jelas agar setiap institusi yang memberikan pelayanan kepada publik dapat benar-benar memberikan pelayanan inklusif dan menyediakan fasilitas yang memadai bagi semua orang.

Secara umum, upaya percepatan ini dapat dilakukan secara internal dan eksternal. Dari sisi internal, upaya untuk mempercepat pembentukan regulasi lokal perlu untuk dilakukan dari sisi pembuat kebijakan sendiri. Pembuat kebijakan yang dimaksud meliputi lembaga legislatif daerah dan pemerintah. Sementara dari sisi eksternal, masyarakat luas dapat memberikan suaranya kepada pemerintah. Mereka dapat mengajukan tuntutan melalui dialog umum, kampanye, maupun membentuk pressure group dengan tujuan untuk menekan pemerintah agar lebih memperhatikan isu aksesibilitas pelayanan publik. Namun, aksi dari masyarakat ini belum cukup siginifikan di Bandung. Aksiaksi yang menyuarakan isu-isu disabilitas, termasuk soal tuntutan penyandang disabilitas kepada pemerintah terkait dengan pelayanan publik, lebih banyak dilakukan oleh komunitas penyandang disabilitas, aktivis yang memiliki perhatian terhadap isu disabilitas, dan lembaga swadaya masyarakat. Karena itu, aksi-aksi dari masyarakat juga perlu untuk ditingkatkan agar pemerintah juga semakin terpacu untuk mengeluarkan kebijakan secara lebih cepat dan esensi kebijakan yang dikeluarkan benar-benar bersifat inklusif.

Kesepuluh, sosialisasi dan kampanye sosial untuk meningkatkan kesadaran. Masyarakat luas masih kurang berperan aktif dalam mendorong percepatan pembentukan kebijakan pro-disabilitas dan perwujudan aksesibilitas yang inklusif. Hal ini bisa terjadi karena kurangnya kesadaran mereka terhadap pentingnya pelayanan publik yang inklusif, sebagaimana yang disebutkan dalam subbab sebelumnya. Untuk menangani hal ini, dibutuhkan sosialisasi secara meluas. Pertama, sosialisasi tentang pentingnya aksesibilitas pelayanan publik yang inklusif perlu 
diberikan kepada aparatur sipil negara (ASN). Melalui sosialisasi ini, ASN diharapkan untuk dapat memberikan pelayanan publik yang tidak diskriminatif. Selain itu, kesadaran para ASN akan hakhak penyandang disabilitas akan mendukung terselenggaranya komunikasi dan koordinasi yang lebih baik dalam sektor pemerintahan. Kedua, kampanye sosial yang berisi dukungan terhadap penyandang disabilitas dan hak-hak mereka sebagai penduduk Bandung perlu untuk disebarluaskan. Normalnya, ada dua jenis kampanye yang bisa dilakukan kalau dilihat dari waktu pelaksanaannya. Kampanye yang pertama dilakukan pada hari-hari tertentu seperti dalam Hari Disabilitas Internasional setiap 3 Desember, sedangkan tipe kedua adalah kampanye yang dilakukan secara terus-menerus dalam bentuk gerakan, baik dalam bentuk aksi di lapangan, melalui media sosial, atau perpaduan keduanya.Kampanya seperti ini dibutuhkan agar disabilitas tetap menjadi isu "hangat" yang beredar di masyarakat. Dengan begitu, masyarakat dapat memberi perhatian lebih terhadap isu tersebut. Di Bandung, kampanye seperti ini belum terlalu populer, meskipun ada komunitaskomunitas yang peduli terhadap isu disabilitas yang melakukannya. Komunitas penggerak isu disabilitas di Bandung memiliki beberapa jenis kegiatan, seperti senam bersama, gerak jalan, dan dialog bersama. Melalui kegiatan-kegiatan tersebut, penyandang disabilitas dapat memberikan dukungan kepada sesama (peer support) maupun menunjukkan eksistensi mereka terhadap masyarakat luas. Ketiga, sosialisasi perlu diberikan kepada organisasi publik dan swasta yang ada di Bandung, terutama terkait pengadaan layanan kepada publik. Aksesibilitas pelayanan publik hanya bisa diwujudkan apabila ada komitmen bersama, khususnya dari penyelenggara pelayanan, baik pemerintah maupun swasta. Hal ini sangat dibutuhkan mengingat di Bandung, belum banyak institusi publik yang menyediakan fasilitas dan pelayanan inklusif. Dari semua fasilitas publik yang ada di Bandung, baru perhotelan yang normalnya memiliki fasilitas untuk penyandang disabilitas. Itu pun baru sebatas fasilitas, karena banyak hotel belum menyediakan pelayanan yang ramah terhadap disabilitas, ditandai dengan ketiadaan staf pelayanan yang memahami bahasa isyarat. Sementara untuk fasilitas publik lain, seperti di bidang pendidikan, kesehatan, dan transportasi, masih banyak gedung yang belum dilengkapi dengan fasilitas dan pelayanan ramah disabilitas. Hal yang sama ditemukan di antara restoran dan pusat perbelanjaan di Bandung. Tidak semua restoran, kafe, dan pusat perbelanjaan bisa dikunjungi oleh 
penyandang disabilitas tanpa bantuan orang lain. Kondisi di atas menunjukkan bahwa rendahnya aksesibilitas pelayanan publik terjadi tidak hanya di institusi pemerintah, tetapi juga swasta. Karena itulah, sosialisasi pentingnya pelayanan publik yang inklusif perlu untuk disampaikan kepada semua institusi.

\section{KESIMPULAN DAN SARAN}

Aksesibilitas pelayanan publik merupakan hak setiap warga negara, tetapi hak tersebut belum bisa dinikmati sepenuhnya oleh para penyandang disabilitas. Masalah ini cukup prevalen di Kota Bandung. Ada banyak fasilitas dan pelayanan publik yang belum memenuhi standar desain universal sehingga tidak dapat digunakan oleh penyandang disabilitas, meskipun sebenarnya sudah didesain untuk mengakomodasi mereka. Hal ini terjadi karena kurangnya pemahaman dan kesadaran akan desain universal sehingga keberadaan fasilitas bagi penyandang disabilitas seringkali hanya menjadi formalitas, sementara banyak fasilitas lainnya belum memiliki desain untuk disabilitas sama sekali.

Perwujudan Kota Bandung menjadi kota ramah disabilitas merupakan suatu isu yang diharapkan dapat menjawab masalah aksesibilitas pelayanan publik di kota tersebut. Namun, dalam kenyataannya, ada banyak tantangan yang muncul sehingga sampai saat ini kota ramah disabilitas masih terbatas sebagai isu saja. Tantangan yang muncul terkait dengan dukungan dan koordinasi antarlembaga pun masih kurang. Membentuk suatu kota menjadi ramah disabilitas membutuhkan komitmen dari semua penyelenggara pelayanan publik. Di Bandung, keduanya masih menjadi masalah karena belum semua organisasi mau berkomitmen untuk menyelenggarakan aksesibilitas pelayanan publik inklusif. Kalau pun sudah ada komitmen, tidak jarang koordinasi, baik antara satu organisasi dengan lainnya maupun antara pimpinan dengan petugas lapangan, seringkali bermasalah sehingga fasilitas dan pelayanan yang dihasilkan belum sepenuhnya inklusif. Tantangan lainnya yang muncul adalah kurangnya kesadaran masyarakat, terlihat dari bagaimana penyandang disabilitas dianggap sebagai orang yang kurang. Hak-hak mereka sebagai warga negara, termasuk hak untuk hidup secara independen, juga belum sepenuhnya dihormati.

Sebagai respons atas tantangantantangan di atas, beberapa strategi perlu untuk diterapkan sebagai upaya untuk mempercepat perwujudan Bandung sebagai kota ramah lingkungan. Strategi pertama yang perlu dilakukan adalah pembentukan regulasi di tingkat daerah sebagai turunan 
dari UU No. 8 Tahun 2016. Regulasi tersebut perlu dikeluarkan secepat mungkin dengan pertimbangan mendalam terhadap aksesibilitas pelayanan publik. Regulasi tersebut juga harus bersifat mengikat, dengan sistem reward and punishment yang jelas. Strategi berikutnya adalah dengan melakukan pengembangan tata kota dengan memperhatikan desain universal. Hal yang sering terjadi di Bandung adalah adanya upaya pembangunan fasilitas publik untuk disabilitas, tetapi fasilitas tersebut tidak benar-benar bisa digunakan. Karena itu, pengembangan berdasarkan desain universal perlu untuk dilakukan. Koordinasi antarlembaga juga perlu untuk ditingkatkan agar tidak ada miskomunikasi dalam melakukan pembangunan. Sementara bagi masyarakat luas, peningkatan kesadaran merupakan strategi yang harus dilakukan, baik melalui sosialisasi maupun kampanye sosial. Peningkatan kesadaran masyarakat ini penting karena semakin banyak orang yang menyadari dan menghormati hak-hak penyandang disabilitas, semakin banyak pula orang yang akan mendukung perwujudan aksesibilitas pelayanan publik yang inklusif.

\section{REFERENSI}

Badan Pusat Statistik. 2017. Jumlah dan Distribusi Penduduk, Diambil kembali dari Badan Pusat Statistik: https://sp2010.bps.go.id/ pada tanggal 8 September 2018 pukul 18.30 WIB.

Bhat, Chandra, et al. 2000. Accessibility Measures: Formulation Considerations and Current Applications. Austin: The University of Texas. Diambil kembali dari usu.ac.id: https://ctr.utexas.edu/wpcontent/uploads/pubs/4938_2.pdf pada tanggal 14 April 2019 pukul 15.00 WIB.

Dinas Sosial Kota Bandung. 2018. Laporan Perkembangan Disablilitas Kota Bandung.

Dwiyanto, Agus. 2012. Manajemen Pelayanan Publik: Peduli, Inklusif dan Kolaboratif. Yogyakarta: Gadjah Mada University Press.

Firdaus, Ferry, \& Fajar Iswahyudi. 2010. Aksesibilitas Dalam Pelayanan Publik Untuk Masyarakat Dengan Kebutuhan Khusus. Jurnal Borneo Administrator. 6 (3). P 1-16

ILO. 2018. Inklusi Penyandang Disabilitas di Indonesia. Jakarta: ILO.

Independent Living Institute. 2018. Campaigns: disability awareness in action resource kit no. 3. Dikutip dari https://www.independentliving.org/ doc s2/daakit32.html, Accessed: [13 June, 2018] Pukul 18.50 WIB.

Kurniawan, Luthfi. J., 2008. Paradigma Kebijakan Pelayanan Publik, Rekonstruksi Pelayanan Publik Menuju Pelayanan yang Adil, Berkualitas, Demokratis dan Berbasis Hak Rakyat. Malang: In-Trans Publishing.

Leksono, et al. 2010. The Influence of Urban Accessibility in Determining 
Average Indicated Land Values for the Region. The XXIV FIG International Congress 2010 Proceeding. Diakses dari https://www.fig.net/resources/procee dings/fig_proceedings/fig2010/paper s/ts10f/ts10f_susilowati_leksono_et_ al_4317.pdf.

Puspitosari, Hesti. 2016. Filosofi Pelayanan Publik. Malang: Setara Press.

Rahayu, Sugi \& Utami Dewi. 2013. Pelayanan Publik bagi Pemenuhan Hak-hak Disabilitas di Kota Yogyakarta. Jurnal Natapraja: Kajian Ilmu Administrasi Negara. 1 (1).

Snider, Harold \& Nazumi Takeda. 2008. Design For All: Implications For Bank Operation. Wold Bank.

Suhendra, Adi. 2017. Strategi Pemerintah Kota Banda Aceh dan Kota Surakarta dalam Mewujudkan Kota Ramah Disabilitas. Matra Pembaruan, 1 (3) p 131-142. Diakses dari doi:0.21787/mp.1.3.2017.131-142

Syafi'ie', M. 2014. Pemenuhan Aksesibilitas Bagi Penyandang Disabilitas. Jurnal Inklusi. 1 (2) $\mathrm{p}$ 269-307.

Vale, David S. 2015. Active accessibility: A review of operational measures of walking and cycling accessibility. The Journal of Transport and Land Use 9 (1), p 209-235. 